\title{
PENGEMBANGAN PAKET PROGRAM COACHING BERBASIS VIDEO UNTUK PENINGKATAN KOMPETENSI MENGAJAR GURU SAINS
}

\author{
Ari Widodo, Riandi, dan Bambang Supriatno \\ FPMIPA Universitas Pendidikan Indonesia (e-mail: widodo@upi.edu;
}

HP. 081321656749)

\begin{abstract}
Developing a Video-Based Coaching Program Package to Improve Science Teachers' Teaching Competencies. A number of programs have been launched by the government to improve teachers' teaching competencies. It seems, however, there is no significant improvement in the practice. This paper presents results of a three-year research project employing the Research and Development ( $R$ \& $D)$ design. In the first year, a needs assessment was conducted to identify teachers' needs for their professional development. Based on the results of the first year, a video-based coaching package was developed in the second year. In the final year, an experimental study was conducted to assess the effectiveness of the coaching package. The study reveals that through the coaching package there is improvement in teachers' ability to reflect on their own practice as well as their teaching competencies.
\end{abstract}

Keywords: video-based coaching, teacher competencies, teacher professionalism, science

\section{PENDAHULUAN}

Usaha pencarian model peningkatan profesionalisme guru tidak pernah henti dilakukan. Beberapa program peningkatan profesionalisme guru telah dilakukan, misalnya PKG, KKG, MGMP, dan yang relatif baru Lesson Study. Program-program yang lebih insidental sifatnya juga telah banyak dilakukan, misalnya penataran, workshop, dan pendidikan lanjut. Meskipun demikian, kegiatan-kegiatan tersebut masih belum memberikan perubahan berarti bagi pembelajaran di dalam kelas. Kondisi ini jelas menuntut alternatif baru dalam usaha peningkatan kemampuan mengajar guru/calon guru (Hinduan, 2005).
Berdasarkan penelitian yang telah peneliti lakukan (Widodo, Riandi, Amprasto, \& Ana Ratna Wulan, 2006) terungkapbeberapa kendala untukmenerapkan hasil-hasil kegiatan peningkatan profesionalisme. Kedala-kendala tersebut berkaitan dengan proses, isi, maupun dukungan pasca pelatihan. Kendala yang berkaitan dengan prosespelatihan/penataran:(1)metode pelatihan pada umumnya berupa ceramah dan diskusi tanpa ada kesempatan bagi guru untuk berlatih menerapkan secara nyata; (2) pelaksanaan pelatihan/penataran bersifat masal sehingga tidak bisa memperhatikan kebutuhan/permasalahan individual setiap guru; (3) kegiatan pelatihan/ 
penataran jarang sekali mendiskusikan permasalahan nyata yang ada di lapangan.

Salah satu kendala penerapan yang terkait dengan isi pelatihan/penataran adalah kurang sesuainya materi pelatihan dengan kebutuhan lapangan. Sebenarnya, materi yang disajikan dapat dipahami dengan baik oleh guru. Dari sisi dukungan pasca pelatihan/penataran, kegiatan yang ada selama ini sebagian besar belum diikuti dengan monitoring dan evaluasi yang memadai. Selain itu, tidak ada evaluasi, dukungan nyata dari sekolah (waktu, sarana, dan dana) juga kurang memadai.

Untuk mengubah praktek mengajar, seorang guru memerlukan lebih dari sekedar penjelasan bagaimana cara mengajar yang baik. Supaya setelah mengikuti suatu program peningkatan kemampuan mengajar guru bisa mempraktekkan apa yang diperoleh, program tersebut harus memenuhi beberapa ciri seperti berikut.

Bisa membuat guru reflektif, artinya bisa mengarahkan guru agar menyadari dan menemukan "kelemahan" dan "kelebihan" yang dimilikinya dalam mengajar (Fischler, 2004). Seseorang tidak akan mau berubah apabila dia tidak menyadari bahwa ada sesuatu yang kurang baik yang harus diperbaiki.

Memperhatikan prinsip-prinsip perubahan konsepsi. Perubahan praktikmengajarharus dimulai dari perubahan konsepsi guru tentang belajar dan mengajar (Davis, 2003; Fischler \& Schröder, 2003; Haney \& McArthur, 2002).
Memperhatikan aspek emosi, pandangan, dan keyakinan guru. Suatu perubahan yang mendasar bukan hanya sekedar melibatkan aspek kognitif, tetapi juga aspek non kognitif (Fischler, 2004; Pintrich, Marx, \& Boyle, 1993).

Memberikan contoh nyata yang berasal dari lapangan (Davis, 2003; Hewson, Tabachnick, Zeichner, \& Lemberger, 1999). Contoh nyata dari lapangan membuat guru yakin bahwa sesuatu yang baru dipelajari adalah sesuatu yang memang bisa dilakukan.

Memberikan dukungan pada saat pelaksanaan di lapangan. Perubahan bukanlah suatu loncatan, namun merupakan suatu proses yang bertahap (Fischler, 2004). Oleh karena itu, guru harus tetap mendapatkan dukungan bantuan pada saat menerapkan apa yang telah dipelajari.

Uraian di atas mengindikasikan perlunya sebuah program peningkatan profesionalisme guru yang lebih bersifat individual yang didasarkan pada motivasi internal guru. Selama ini, program peningkatan profesionalisme guru lebih bersifat massal dan top-down sehingga kurang memperhatikan aspek motivasi guru serta kebutuhan individual guru. Salah satu alternatif program peningkatan profesioalisme guru yang memperhatikan motivasi dan kebutuhan individual guru adalah coaching.

Coaching merupakan pembimbingan yang dilakukan secara intensif dan sistematis dalam rangka membantu seseorang meningkatkan kemampu- 
annya atau mengatasi masalah yang dihadapinya (Greif, 2008). Coaching lazim digunakan dalam bidang pengembangan profesionalisme seseorang dalam bidang pekerjaannya (Loos dalam Fischler, Schroeder, Tonhaeuser \& Zedler, 2002). Coaching belum banyak digunakan dalam dunia pendidikan, walaupun sesungguhnya sudah banyak digunakan dalam dunia industri dan perusahaan.

Pada umumnya, coaching dilakukan melalui interaksi langsung antara coachee dan coach. Meskipun demikian, keberadaan coach tidak harus selalu berupa orang, namun bisa juga digantikan oleh sebuah program coaching (Greif, 2008). Dalam kasus yang demikian (selfcoaching), coachee diberikan sebuah program yang secara khusus dirancang untuk membuat coachee bisa melakukan refleksi dan kemudian dibimbing pada pencapaian tujuan yang diinginkan.

Pemanfaatan metode coaching dalam peningkatan profesionalisme guru masih sangat jarang sebab peningkatan profesionalisme guru biasanya masih dilakukan secara massal melalui penataran, dan workshop. Mengingat jumlah guru di Indonesia yang sangat banyak, coaching secara individual yang melibatkan antara seorang coachee dan coach tentu tidak mungkin dilakukan. Oleh karena itu, dalam penelitian ini dipilih coaching dengan menggunakan paket Program Coaching Berbasis Video.

Hasil penelitian tentang coaching berbasis video (Fischler, Schroeder, Tonhaeuser, \& Zedler, 2002; Schröder \& Fischler, 2003) ditemukan bahwa guru yang telah mengikuti coaching memperlihatkan peningkatan yang berarti dalam cara mengajar. Setelah mengikuti coaching, pandangan guru tentang cara mengajar yang efektif menjadi berubah dan hal tersebut diperlihatkannya dalam kegiatan pembelajaran yang berubah dari pembelajaran yang berpusat pada guru (ceramah) menjadi pembelajaran yang berpusat pada siswa. Analisis terhadap kegiatan pembelajaran guru tersebut juga memperlihatkan bahwa guru mengajar dengan menggunakan metode pembelajaran yang lebih bervariasi (Schroeder \& Fischler, 2003).

Berdasarkan pertimbangan-pertimbangan yang telah diuraikan, coaching berbasis video dinilai bisa menjadi salah satu alternatif metode peningkatan kemampuan mengajar guru. Berdasarkan hasil analisis terhadap penyelenggaraan program profesionalisme guru di Indonesia, Adey, Hewitt, Hewitt dan Landau (2004) menyarankan agar coaching bagi guru-guru lebih banyak lagi dilakukan. LoucksHorsley, Stiles, Mundry, dan Hewson (2010) memasukkan coaching sebagai salah satu program peningkatan profesionalisme guru yang penting selain metode lain, misalnya lesson study, action research, dan monitoring.

Terdapat beberapa alasan mengapa coaching berbasis video pembelajaran bisa meningkatkan kemampuan mengajar guru sains, seperti berikut.

Coaching berbasis rekaman video pembelajaran memberikan kesempatan kepada guru untuk mengamati kegiatan pembelajaran yang 
telah dilakukannya. Dengan demikian, guru didorong untuk bisa melakukan refleksi dan self-evaluation, terhadap pengetahuannya, keyakinannya, dan juga keterampilan mengajarnya.

Coaching berbasis rekaman video pembelajaran memungkinkan guru untuk memperoleh masukan dan diskusi yang produktif dengan ahli pembelajaran atau guru lain. Karena setelah mengamati rekaman video pembelajaran dilakukan diskusi dengan ahli pembelajaran atau guru lain. Kondisi ini juga memfasilitasi perubahan pandangan guru tentang cara mengajar yang baik.

Coaching berbasis rekaman video pembelajaran menggabungkan pendekatan individual dan pendekatan kelompok. Guru memiliki kesempatan untuk mengkaji pandangan serta praktik yang biasa dilakukan serta bagaimana cara meningkatkannya.

Coaching berbasis rekaman video pembelajaran memberikan kesempatan kepada guru untuk mengamati pembelajaran yang dilakukan guru lain sehingga membantu guru untuk menemukan ide-ide baru untuk memperkaya khazanah pengetahuan tentang pembelajaran.

Coaching berbasis rekaman video pembelajaran bukan hanya memfokuskan pada proses pemberian nasihat saja, namun juga memberikan dukungan pada saat guru menerapkan perubahan yang diinginkan.
Pada coaching berbasis video, coachee diberi sejumlah video pembelajaran yang telah dipilih sehingga guru akan tahu betul apa yang harus diperbaiki dan bagaimana memperbaikinya. Pengetahuan baru yang diperoleh guru melalui program coaching juga lebih aplikatif sebab pengetahuan tersebut adalah pengalaman nyata sesama guru dan bukan penjelasan teoretis atasan, ahli, atau penatar.

Secara umum, coaching berlangsung dalam empat tahapan yang terstruktur, yaitu: orientasi, klarifikasi, pemecahan/perubahan, dan penutup (Schröder \& Fischler, 2003).

\section{Tahap Orientasi}

Tahap ini merupakan tahapperkenalan dan tahap pengkondisian agar tercipta suasana yang saling mempercayai. Berdasarkan kesepakatan bersama antara coachee (guru) dan coach, ditentukan hal-hal yang akan menjadi fokus utama kegiatan coaching. Dalam konteks coaching berbasis rekaman video pembelajaran, rekaman pembelajaran yang telah dilakukan guru tersebut menjadi bahan utama untuk menentukan perbaikan yang akan dilakukan. Coach akan membantu guru untuk menemukan hal-hal apa yang perlu diubah/diperbaiki.

\section{Tahap Klarifikasi}

Pada tahap ini, dilakukan analisis permasalahan. Masalah yang akan dipecahkan diuraikan sehingga jelas mana permasalahan utama dan juga permasalahan mana yang akan dipecahkan terlebih dahulu. Berdasarkan rekaman video yang telah dianalisis 
bersama, coach akan membantu coachee mencari akar permasalahan (permasalahan utama) yang perlu terlebih dahulu dicari solusinya.

\section{Tahap Pemecahan (Perubahan)}

Pada tahap ini, coachee dengan bantuan coach berusaha mencari solusi terhadap permasalahan yang dihadapi. Coach berusaha memberikan saran dan alternatif-alternatif, namun coachee sendirilah yang harus mengembangkan solusi permasalahan yang dihadapi. Paket program coaching" yang berisi cuplikan rekaman video pembelajaran yang "baik" dan yang "kurang baik" akan diputar agar coachee dapat mengembangkan ide guna mengatasi permasalahan yang dihadapinya. Coach juga akan memberikan saran dan masukan kepada coachee untuk meningkatkan pengetahuan dan keterampilan.

\section{Tahap Penutup}

Pada tahap ini, dilakukan evaluasi terhadap apa yang telah dicapai coachee dari proses coaching. Hal-hal yang pada tahap pendahuluan disepakati untuk diubah/diperbaiki akan dinilai apakah tujuan tersebut telah tercapai. Ketika coachee tampil mengajar, coach akan mengobservasi dan merekam kegiatan pembelajaran tersebut sehingga coach maupun coachee dapat mengamatinya dan menilai kemajuan yang telah dicapai.

\section{METODE}

Penelitian yang dilakukan merupakan Research and Deevelopment (Gall, Gall \& Borg \& Gall, 2003) yang ber- langsung selama tiga tahun. Penelitian dilakukan dalam tiga tahap yang tiap-tiap tahap berlangsung selama satu tahun (Gambar 1).

\section{PENELITIAN TAHAP PERTAMA (TAHUN PERTAMA)}

Pada tahun pertama, dilakukan penelitian deskriptif untuk mendapatkan gambaran kemampuan mengajar guru dan calon guru biologi. Untuk itu, dilakukan perekaman terhadap proses pembelajaran biologi di sejumlah sekolah di Kota Bandung dan sekitarnya. Berdasarkan wilayah yang ada, dipilih sebanyak 10 orang guru dan 5 orang calon guru biologi. Pembelajaran yang dilakukan oleh para guru dan calon guru direkam secara utuh dengan menggunakan video kamera. Rekaman video pembelajaran tersebut selanjutnya dianalisis untuk mengetahui kemampuan pedagogi mereka. Analisis video dilakukan dengan menggunakan software "Videograph".

Pada tahun pertama ini, juga dilakukan studi pengembangan untuk mengembangkan blueprint paket program coaching. Untuk keperluan ini, dipilih sejumlah cuplikan video yang secara pedagogi dinilai "baik" dan juga sejumlah cuplikan video yang dinilai "kurang baik". Cuplikan-cuplikan video tersebut disusun secara acak dan guru diminta menilai cuplikancuplikan video tersebut. Tujuan kegiatan ini untuk mengidentifikasi pengetahuan guru tentang aspek pedagogi pembelajaran biologi. 
Tahap Sifat Kajian Metode

Langkah Penelitian

Teoritik

Studi

dokumentasi

Analisis teoretis tentang peningkatan
profesionalisme guru/calon guru dan coaching

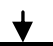

I Empirik Studi deskriptif

Perekaman kegiatan pembelajaran guru/calon guru

$\downarrow$

Analisis rekaman video pembelajaran

Teoretik Studi deskriptif Analisis pola treatment untuk tiap jenis masalah

Teoretik Studi pengembangan

\begin{tabular}{|c|c|}
\hline $\begin{array}{c}\text { Pengembangan } \\
\text { blueprint "Paket } \\
\text { Program Coaching" }\end{array} \quad \begin{array}{c}\text { Pengembangan } \\
\text { instrumen untuk } \\
\text { mengukur efektivitas } \\
\text { program coaching }\end{array}$ \\
\hline
\end{tabular}

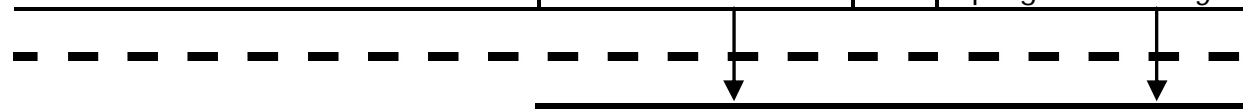

Empirik Studi pra

eksperimen

Uji coba "Paket Program Coaching"

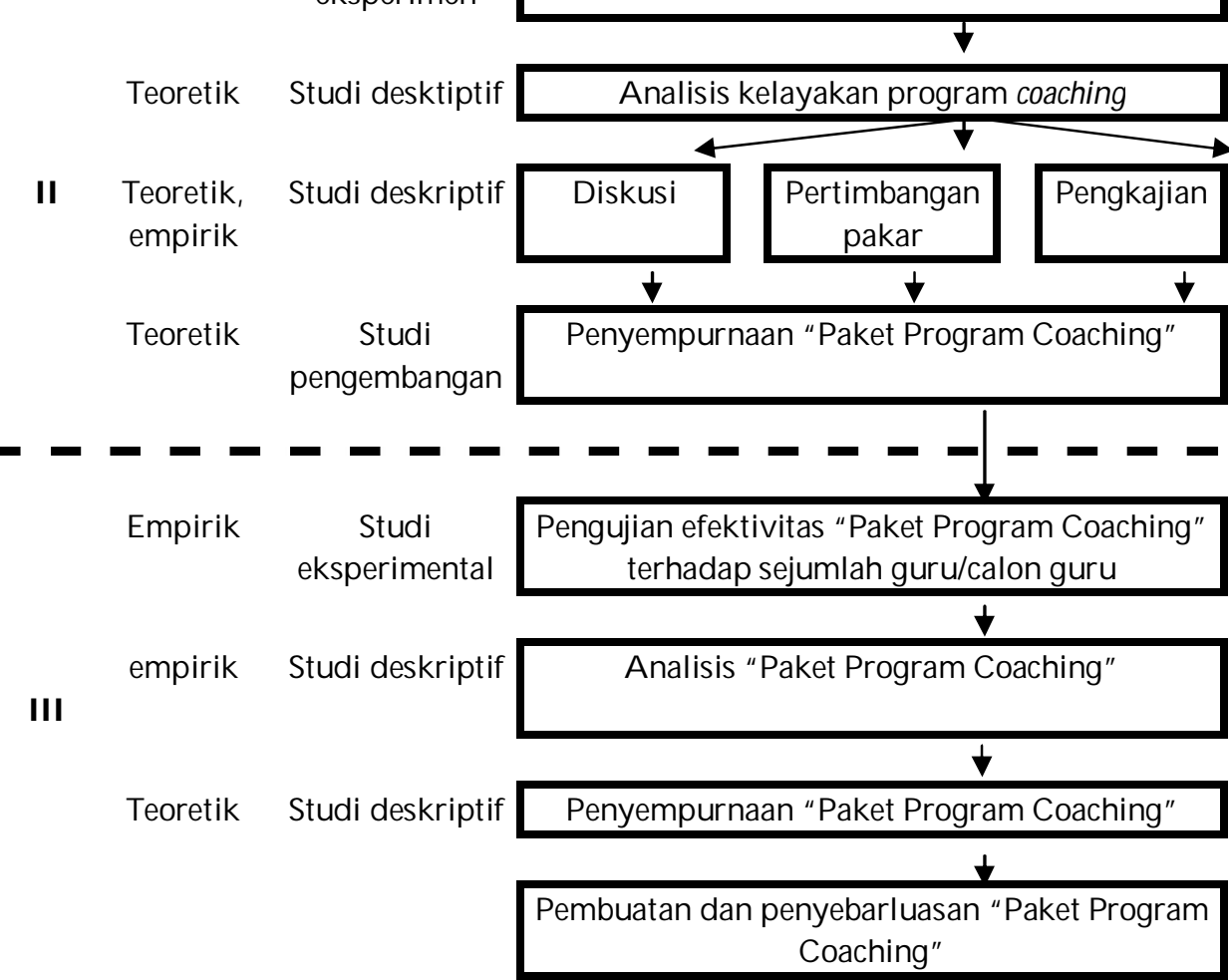

Gambar 1. Tahapan Penelitian 


\section{TAHAP KEDUA (TAHUN KEDUA)}

Pada tahun kedua, dengan menggunakan metode pra eksperimen dilakukan pengujian secara terbatas terhadap blueprint paket program coaching yang telah dikembangkan. Uji coba secara terbatas dilakukan dengan melibatkan beberapa guru sains. Selain uji coba, juga dilakukan konsultasi dengan ahli yang komputer dan ahli pendidikan.

Pada tahun kedua, juga dikembangkan video rujukan. Video ini merupakan pembelajaran yang telah diskenario secara khusus sehingga memunculkan aspek-aspek yang akan dilatihkan. Video rujukan ini selanjutnya disatukan dengan sejumlah video lain yang diambil dari sejumlah pembelajaran.

\section{TAHAP KETIGA (TAHUN KE- TIGA)}

Pada tahun ketiga, paket program coaching diuji efektivitasnya melalui penelitian eksperimental. Penelitian dilakukan terhadap sejumlah guru IPA di Kota Bandung dan Kota Cimahi. Kegiatan penelitian yang dilakukan seperti berikut.

> Perekaman kegiatan pembelajaran sebelum coaching. Kegiatan pembelajaran yang dilakukan oleh setiap guru direkam oleh peneliti untuk dianalisis dan dijadikan bahan coaching.

Pelaksanaan coaching. Setiap guru diberikan satu paket program coaching yang terdiri dari videoanalyzer, rekaman pembelajaran guru yang bersangkutan, cuplikan beberapa video pembelajaran dari guru lain, dan video rujukan. Selanjutnya, guru secara individual memanfaatkan paket program coaching.

Perekaman kegiatan pembelajaran setelah coaching. Setelah melakukan coaching, pembelajaran yang dilakukan oleh guru direkam sekali lagi untuk dianalisis.

\section{HASIL PENELITIAN \\ PROFIL KEMAMPUAN DASAR MENGAJAR GURU SAINS}

Pada tahun pertama, dilakukan perekaman pembelajaran terhadap sejumlah guru sains. Rekaman video tersebut selanjutnya dianalisis secara rinci untuk mengetahui berapa lama waktu yang diperlukan guru untuk membuka dan menutup pelajaran. Analisis terhadap kegiatan pembelajaran yang dilakukan guru berhasil diidentifikasi bahwa guru sains lemah dalam keterampilan dasar mengajar, baik dalam hal membuka pelajaran maupun menutup pelajaran (Tabel 1).

Secara umum, waktu yang digunakan guru/kalon guru untuk membuka pelajaran sekitar 8,2 menit. Alokasi waktu yang demikian cukup logis sebab pada umumnya alokasi waktu membuka yang direncanakan guru dalam perencanaan pembelajaran berkisar antara 5-10 menit. Namun demikian, terdapat variasi yang cukup besar (dari 2,3 menit hingga 16,7 menit). 
Tabel 1. Gambaran Kemampuan Dasar Mengajar Guru Sains

\begin{tabular}{|c|c|c|c|}
\hline No & $\begin{array}{l}\text { Keterampilan Dasar } \\
\text { Mengajar }\end{array}$ & $\begin{array}{c}\text { Komponen Keterampilan Dasar } \\
\text { Mengajar }\end{array}$ & $\begin{array}{l}\text { Durasi Waktu } \\
\text { (Menit) }\end{array}$ \\
\hline \multirow{6}{*}{1} & \multirow{5}{*}{ Membuka pelajaran } & a. Menarik perhatian & 2,5 \\
\hline & & b. Memberi acuan & 1,9 \\
\hline & & c. Menimbulkan motivasi & 2,0 \\
\hline & & d. Membuat kaitan & 1,8 \\
\hline & & Total & 8,2 \\
\hline & \multirow{4}{*}{ Menutup pelajaran } & a. Mengulas kembali & 5,5 \\
\hline \multirow{3}{*}{2} & & b. Mengevaluasi & 0,4 \\
\hline & & c. Menjelaskan bahan berikutnya & 0,6 \\
\hline & & Total & 6,5 \\
\hline
\end{tabular}

Secara umum, waktu yang digunakan guru/calon guru untuk menutup pelajaran berkisar 6,5 menit. Sekalipun tidak ada rumusan pasti tentang seberapa lama waktu yang harus dialokasikan untuk menutup pelajaran, namun secara umum 5-10 menit merupakan alokasi waktu yang cukup logis. Meskipun demikian apabila dikaji secara lebih rinci, terlihat adanya variasi yang sangat besar. Ada guru yang menutup pelajaran dengan sangat tiba-tiba (hanya perlu waktu sekitar 0,5 menit), namun ada juga guru yang menutup pelajaran hingga 24 menit.

\section{PENGEMBANGAN PAKET PRO- GRAM COACHING}

Salah satu tahapan penting dalam penelitian ini adalah pengembangan Paket Program Coaching. Untuk itu, telah dikembangkan sebuah program untuk analisis video yang diberi nama "Videoanalyzer" (Gambar 2).

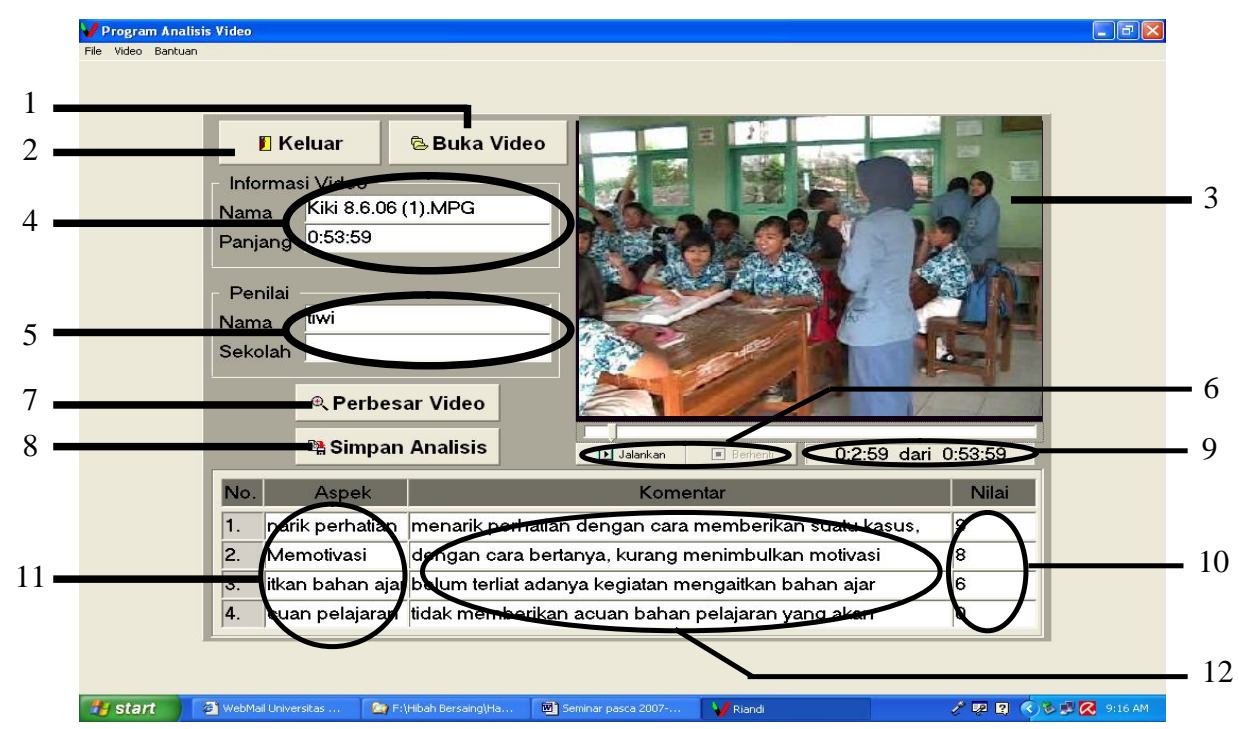

Gambar 2. Tampilan Videoanalyzer 
Keterangan:

1. Tombol untuk membuka file video

2. Tombol keluar program video analyzer

3. Jendela tampilan video

4. Identitas file video

5. Identitas penganalisis

6. Tombol untuk menjalankan dan memberhentikan video

7. Tombol untuk memperbesar tampilan video

8. Tombol untuk menyimpan hasil analisis apabila telah selesai

9. Penunjuk durasi video dan alur waktu putaran video

10. Kolom untuk mencantumkan nilai hasil analisis setiap aspek

11. Kolom jenis aspek yang dikomentari/dinilai

12. Kolom untuk menuliskan komentar setiap aspek

Paket Program Coaching tersebut telah melalui serangkaian uji coba dan penyempurnaan. Uji coba dilakukan kepada mahasiswa, guru pemula dan guru yang cukup berpengalaman. Untuk keperluan penyempurnaan Paket Program Coaching juga telah dilakukan judgement dari ahli dan ahli pembelajaran. Berdasarkan hasil judgement ahli, ada beberapa hal yang diperbaiki, antara lain seperti berikut.

\section{Ukuran Huruf}

Proporsi antara huruf yang ada di menu program dengan huruf yang ada di dalam layar utama dibuat lebih seimbang. Huruf, tombol dan input teks dibuat lebih sederhana sehingga tidak menghabiskan ruang yang terlalu besar dalam layar utama dengan tetap memperhatikan fungsionalitas dan tampilan yang menarik.

\section{Tampilan Layar}

Tampilan antara menu program dengan menu layar utama dibuat full screen sehingga lebih nyaman bagi pengguna karena tampilan lebih kompak dan tidak terpisah jauh.

\section{Pemilihan Model Warna}

Karena pengguna aplikasi ini mungkin menggunakannya dalam durasi waktu yang cukup lama, pemilihan warna dipertimbangkan sehingga pengguna tidak terlalu cepat lelah. Setelah melihat satu tayangan, pengguna akan melihat tampilan aplikasi secara penuh. Saat itu mata pengguna dapatmelakukan relaksasidengan melihat tampilan warna yang jauh lebih menarik dan terkesan mencerahkan.

Agar coachee memperoleh gambaran tentang pembelajaran yang baik, pada tahap kedua juga dikembangkan sebuah video rujukan. Karena video ini akan menjadi rujukan, maka pembelajaran video ini merupakan pembelajaran yang diskenariokan. Video rujukan ini dibuat secara khusus dengan memunculkan aspek-aspek kunci dalam melaksanakan proses belajar mengajar.

\section{UJI EFEKTIVITAS PAKET PRO- GRAM COACHING BERBASIS VIDEO}

Pada tahun ketiga, sejumlah guru sains menggunakan paket program coaching yang telah dikembangkan di tahun kedua. Sebelum dan sesudah menggunakan paket program coaching tersebut, pembelajaran yang dilaku- 
kan oleh guru direkam dan dianalisis untuk mengetahui ada tidaknya peningkatan. Data yang diperoleh dari hasil observasi kinerja guru ketika membuka dan menutup pembelajaran disajikan pada Gambar 3 dan Gambar 4.

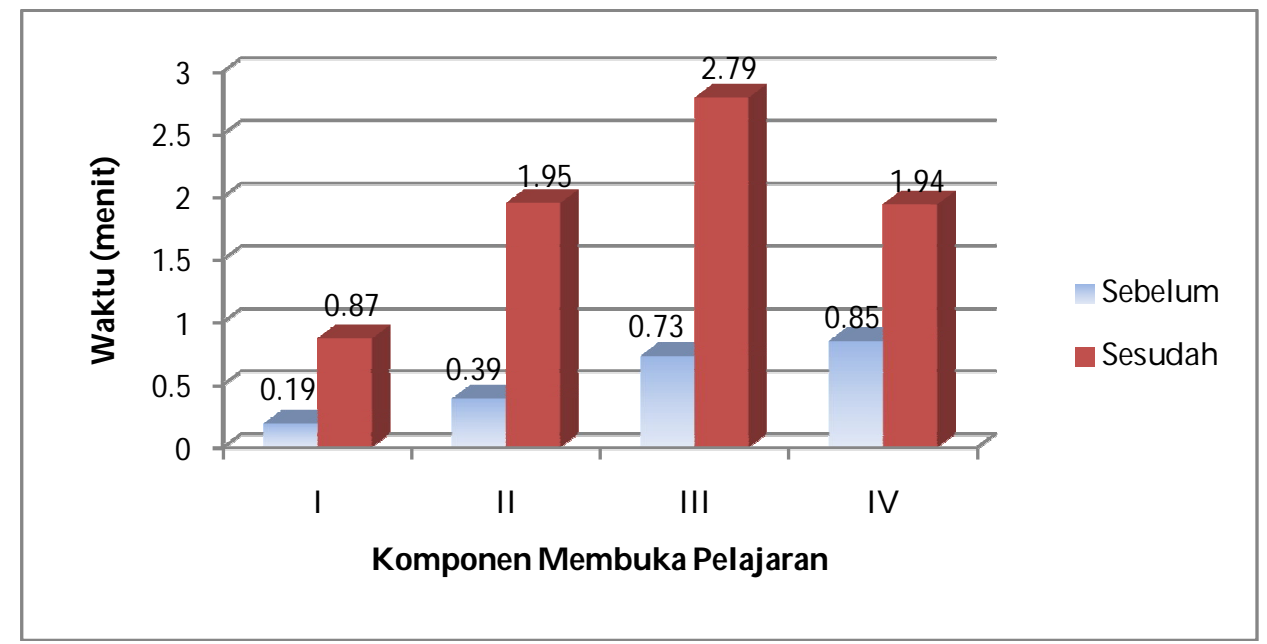

Keterangan:

$\begin{array}{ll}\text { I = Menarik perhatian } & \text { II = Menimbulkan motivasi } \\ \text { III = Memberikan acuan } & \text { IV = Membuat kaitan }\end{array}$

Gambar 3. Durasi Waktu yang Digunakan Guru dalam Membuka Pelajaran Sebelum dan Sesudah Mengikuti Coaching

Gambar 3 menunjukkan terjadinya peningkatan waktu yang digunakan guru dalam semua komponen keterampilan membuka pelajaran (dari 2,17 menit pada observasi awal menjadi 7,55 menit pada observasi akhir) sehingga terjadi peningkatan waktu selama 5,38 menit. Ini berarti membuka pelajaran telah dilaksanakan dengan baik. Berdasarkan rujukan Puskur (2007), waktu yang digunakan untuk membuka pelajaran antara 5-10 menit.

Secara umum setelah mengikuti coaching guru bisa memunculkan komponen-komponen membuka pelajaran dalam durasi waktu yang memadai.
Peningkatan tertinggi terjadi pada komponen memberikan acuan belajar. Ini berarti guru telah menyadari pentingnya membuka pelajaran sebagai persiapan bagi siswa untuk belajar.

Terkait dengan kemampuan guru menutup pelajaran, program coaching berbasis video juga bisa membantu guru dalam meningkatkan kemampuan mereka dalam menutup pelajaran (Gambar 4). 


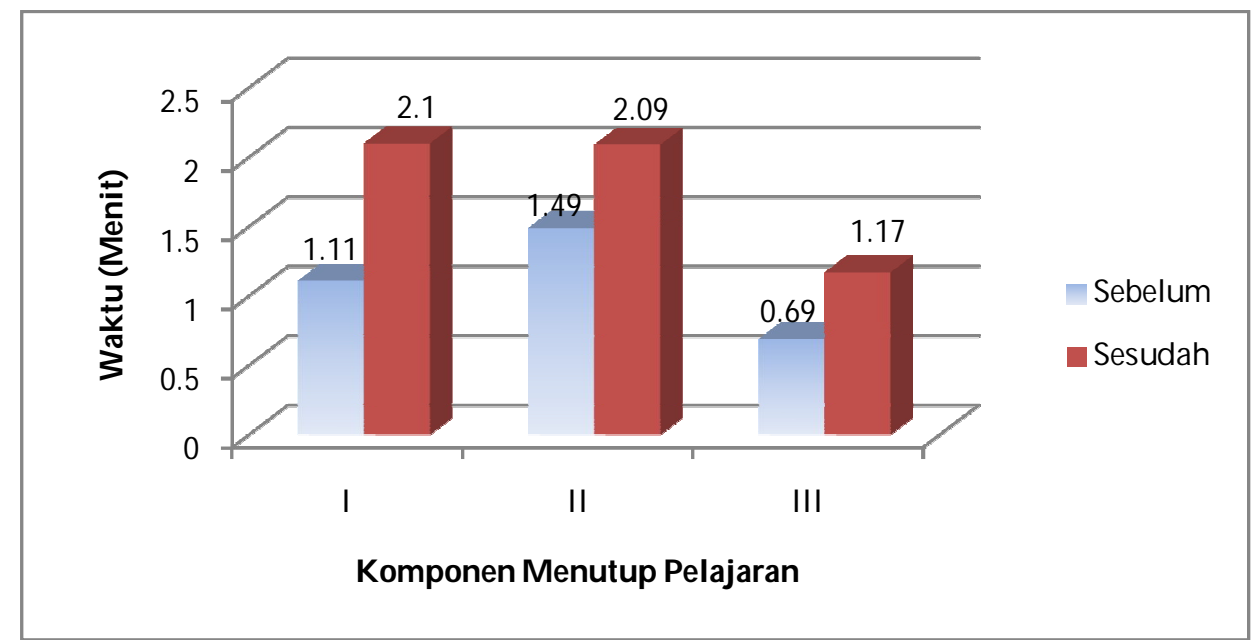

Keterangan:

I = Meninjau kembali

II = Mengevaluasi

III = Tindak lanjut

Gambar 4. Durasi Kemunculan Komponen Menutup Pelajaran antara Sebelum dan Sesudah Mengikuti Coaching

Gambar 4 menunjukkan bahwa sebelum menggunakan paket coaching berbasis rekaman video waktu yang digunakan guru untuk menutup pelajaran hanya 3,29 menit. Hal ini jelas terlalu singkat apabila didasarkan padakriteria yang dikeluarkan oleh Puskur (2007), yaitu selama 5-10 menit. Setelah menggunakan paket program coaching berbasis video, guru lebih menyadari pentingnya kegiatan menutup pelajaran sehingga secara sadar mengalokasikan waktu untuk menutup pelajaran. Secara total, setelah mengikuti coaching guru menggunakan 5,36 menit untuk menutup pelajaran sehingga sudah sesuai dengan rentang waktu yang dianjurkan Puskur ( 2007).

Komponen tindak lanjut mengalami peningkatan waktu, sama seperti komponen keterampilan menu- tup pelajaran lainnya. Tindak lanjut perlu dilakukan dan ditingkatkan guru, sama halnya dengan komponen menutup pelajaran lainnya. Hal ini sesuai dengan pendapat Hasibuan (2005) yang menyatakan bahwa sebagai kegiatan akhir setelah melakukan evaluasi, perlu memberikan kegiatan tindak lanjut berupa tugastugas kokurikuler sebagai bahan pengayaan atau pemantapan terhadap bahan yang diajarkan selama tatap muka.

\section{PEMBAHASAN}

Secara umum, keterampilan mengajar guru meningkat setelah diberikan paket coaching berbasis rekaman video. Hal ini berarti bahwa paket coaching bermanfaat bagi peningkatan keterampilan mengajar guru. Hasil ini sejalan dengan penelitian terdahulu 
(Fischler, Schroeder, Tonhaeuser, \& Zedler, 2002; Schröder \& Fischler, 2003) yang mengungkapkan bahwa guru yang telah mengikuti coaching memperlihatkan peningkatan yang berarti dalam cara mengajarnya.

Setelah menggunakan paket program coaching, guru lebih menyadari bahwa membuka dan menutup pelajaran bukanlah sekedar mengucapkan salam, atau memeriksa kehadiran siswa, tetapi membuka dan menutup pelajaran memiliki makna penting dalam belajar. Sebagaimana diungkapkan dalam penelitian sebelumnya, salah satu keterampilan dasar mengajar yang kurang dikuasai dengan baik oleh guru sains adalah keterampilan membuka dan menutup pelajaran (Widodo, Sumarno, Nurjhani \& Riandi, 2007; Widodo, Riandi, \& Hana', 2007).

Setelah pemberian paket coaching, guru betul-betul berusaha untuk bisa menarik perhatian siswa sehingga waktu yang mereka gunakan juga lebih lama. Beberapa strategi yang mereka gunakan untuk menarik perhatian antara lain dengan menunjukkan specimen hidup atau specimen awetan kepada siswa. Penggunaan specimen ternyata bisa membuat siswa tertarik dengan pelajaran.

Hampir semua guru menerapkan komponen meninjau kembali dengan merangkum materi pelajaran. Kegiatan merangkum pelajaran dilakukan oleh guru dengan cara mengajukan pertanyaan terlebih dahulu pada siswa dan meminta siswa untuk merangkum materi yang telah dipelajari, kemudian guru membenarkan atau meluruskan rangkuman siswa apabila tidak tepat. Siswa membutuhkan penegasan terhadap apa yang sudah dipelajari saat kegiatan pembelajaran. Membuat kesimpulan merupakan kegiatan yang penting dari segi pencapaian target materi pelajaran hari itu.

Pemberian paket coaching berbasis rekaman video juga menyebabkan terjadinya peningkatan pada komponen motivasi. Semua guru pada observasi akhir telah memunculkan komponen motivasi yang lebih tinggi. Hal ini menggambarkan bahwa semua guru sudah menyadari pentingnya komponen menimbulkan motivasi.

Cara yang dilakukan guru untuk menimbulkan motivasi pada penelitian ini antara lain dengan mengajukan pertanyaan pada siswa, bersikap ramah dan penuh semangat dalam berinteraksi dengan siswa, dan menggunakan media specimen hidup berupa beberapa jenis kerang, bekicot, siput, dancumi-cumi.Guru juga memberikan penghargaan kepada siswa yang perpartisipasi aktif untuk mendorong siswa-siswa lain melakukan hal serupa.

Melalui partisipasi dalam coaching, guru ternyata bisa lebif reflektif (Fischler, 2004) sehingga muncul keinginan untuk memperbaiki performa mengajarnya. Selain itu, video model yang menjadi salah satu bahan coaching dapat memberikan inspirasi bagi guru untuk mengembangkan pembelajaran sebagaimana yang diinginkan. Selain itu, dari wawancara juga terungkap bahwa paket coaching dapat meningkatkan motivasi guru untuk 
mempelajari dan menerapkan keterampilan mengajar dengan benar. Dari paket ini, mereka dapat mengetahui contoh penerapan keterampilan mengajar yang baik.

Hasil penelitian ini mendukung pendapat Greif (2008) yang menyatakan bahwa coaching tidak harus selalu dilakukan secara konvensional dengan melibatkan interaksi langsung antara langsung antara coachee dan coach. Keberadaan coach bisa juga digantikan oleh sebuah program coaching. Hasil penelitian ini dapat diterapkan di Indonesia mengingat jumlah guru yang sangat banyak. Di masa mendatang, guru tidak harus selalu bertemu dengan penatar/coach, namun bisa melakukan coaching secara mandiri sesuai dengan kebutuhannya dengan memanfaatkan paket program coaching yang secara khusus disiapkan untuk mengembangkan kemampuan tertentu.

\section{KESIMPULAN}

Setelah melalui serangkaian uji coba dan perbaikan, Paket Program Coaching Berbasis Video yang dikembangkan sudah bisa digunakan untuk melakukan coaching. Paket program coaching yang dikembangkan terdiri dari sebuah software yang diberi nama Videoanalyzer dan sejumlah video pembelajaran yang secara khusus dipilih dan dibuat untuk membantu guru mengembangkan kompetensi mengajar mereka pada keterampilan tertentu.

Setelah memanfaatkan Paket Program Coaching Berbasis Video, guru menunjukkan peningkatan kompeten- si mengajar mereka. Partisipasi dalam coaching berbasis video dapat meningkatkan kemampuan guru dalam membuka dan menutup pelajaran sehingga kegiatan pembelajaran bisa berlangsung dengan lebih baik. Guru yang telah menggunakan paket program coaching berbasis video, bukan hanya menyadari pentingnya membuka dan menutup pelajaran, namun mereka juga telah menerapkan hasil coaching dalam pembelajaran di dalam kelas.

\section{UCAPAN TERIMA KASIH}

Tulisan ini didasarkan pada hasil penelitian "Hibah Bersaing" dari tahun 2007 sampai 2009 yang didanai oleh Direktorat Jenderal Pendidikan Tinggi, Depdiknas.

\section{DAFTAR PUSTAKA}

Adey, P., Hewitt, G., Hewitt, J. \& Landau, N. 2004. The Professional Development of Teachers: Practice and Theory. Dordrecht: Kluwer Academic Publishers.

Davis, K. S. 2003. "Change is Hard": What Science Teachers are Telling Us about Reform and Teacher Learning of Innovative Practices". Science and Education, LXXXVII (1), 3-30.

Fischler, H. 2004. "Grundsaetze Fachdidaktischen Coachings". In A. Pitton (Ed.), Chemie- und Physikdidaktische Forschung und Naturwissenschaftliche Bildung. Muenster: LIT Verlag. 
Fischler, H., \& Schröder, H.-J. 2003. "Fachdidaktisches Coaching für Lehrende in der Physik". Zeitschrift für Didaktik der Naturwissenschaften, IX (1), 43-62.

Fischler, H., Schroeder, H.-J., Tonhaeuser, C., \& Zedler, P. 2002. "Unterrichtssckripts und Lehrerexpertise: Bedingungen ihrer Modifikation". Zeitschrift für Paedagogik, XLV (1), 157-172.

Gall, M. D., Gall, J. P. \& Borg, W. R. 1989. Educational Research: An Introduction. Boston: Pearson Education.

Greif, S. 2008. Coaching und Ergebnisorientierte Selbstreflektion. Hogrefe: Goettingen.

Haney, J. J., \& McArthur, J. 2002. "Four Case Studies of Prospective Science Teachers' Beliefs Concerning Constructivist Teaching Practices". Science and Education, LXXXVI (3), 783-802.

Hasibuan, J.J. 2006. Proses Belajar Mengajar. Bandung: Remaja Rosdakarya.

Hewson, P. W., Tabachnick, B. R., Zeichner, K. M., \& Lemberger, J. 1999. "Educating Prospective Teachers of Biology: Findings, Limitations, and Recommendations". Science Education, LXXXIII (3), 373-384.
Hinduan, A. A. 2005. Meningkatkan Profesionalisme Guru IPA Sekolah. Paper Presented at the Seminar Nasional Himpunan Sarjana dan Pemerhati Pendidikan Indonesia, Bandung.

Loucks-Horsley, S., Stiles, K. E., Mundry, S., Love, N. \& Hewson, P. W. 2010. Designing Professional Development for Teachers of Science and Mathematics. California: Corwin.

Pintrich, P. R., Marx, R. W., \& Boyle, R. A. 1993. "Beyond Cold Conceptual Change: The Role of Motivational Beliefs and Classroom Contextual Factors in the Process of Conceptual Change". Review of Educational Research, LXIII (2), 167-199.

Puskur. 2007. Panduan Pengembangan Pembelajaran IPA Terpadu. Jakarta: Balitbang Depdiknas.

Schröder, H.-J., \& Fischler, H. 2003. Subject-related Pedagogical Coaching: A Case Study. Paper Presented at the ESERA Conference, Noordwijkerhout, The Netherlands.

Schroeder, H.-J., \& Fischler, H. 2004. "Fachdidaktisches Coaching: Methoden der Beratung an einem Fallbeispliel". In A. Pitton (Ed.), Chemie- und Physikdidaktische Forschung und $\mathrm{Na}$ turwissenschaftliche Bildung. Muenster: LIT Verlag. 
Widodo, A. Riandi, Amprasto \& Ana Ratna Wulan. 2006. Analisis dampak Program-program Peningkatan Profesionalisme Guru Sains terhadap Peningkatan Kualitas Pembelajaran Sains di Sekolah. Laporan penelitian Hibah Kebijakan Balitbang Depdiknas.

Widodo, A. Sumarno, U., Nurjhani, M. \& Riandi. 2007. "Peranan Lesson Study dalam Peningkatan Ke- mampuan Mengajar Mahasiswa Calon Guru". Varidika, IX (1), 15-28.

Widodo, A. Riandi \& Hana, N. 2007. Pengembangan Paket Program Coaching Berbasis Video untuk Meningkatkan Kemampuan Mengajar Guru dan Calon Guru Biologi. Laporan penelitian Hibah Bersaing. 